\title{
Adsorptive Stripping Voltammetric Determination of Nitroimidazole Derivative on Multiwalled Carbon Nanotube Modified Electrodes: Influence of Size and Functionalization of Nanotubes
}

\author{
Paola Jara-Ulloa, Paulina Cañete-Rosales, Luis J. Núñez-Vergara and Juan A. Squella* \\ Bioelectrochemistry Laboratory, Chemical and Pharmaceutical Sciences Faculty, \\ University of Chile, Postal Code 838492 Santiago, Chile
}

\begin{abstract}
1-Metil-4-nitro-2-bromometilimidazol (4-NimMeBr) foi eletroquimicamente reduzido em eletrodos de mercúrio, carbono vítreo e carbono vítreo modificado com nanotubos de carbono de parede múltipla (MWCNT). 4-NimMeBr adsorveu no eletrodo de carbono vítreo modificado com nanotubos de carbono, tornando possível a implementação de um método de quantificação por voltametria de redissolução adsortivo (ASV). 4-NimMeBr foi usado como protótipo de composto eletroativo para estudar o efeito do tamanho dos nanotubos e de sua funcionalização por oxidação, na resposta eletroquímica do eletrodo modificado. Nanotubos oxidados formaram melhores dispersões em água, produzindo uma superfície de eletrodo com alta densidade de MWCNT, como mostram os dados obtidos por microscopia de varredura eletroquímica (SECM). Sob as condições otimizadas, a corrente de pico foi proporcional à concentração de 4-NimMeBr no intervalo de $10^{-6} \mathrm{~mol} \mathrm{~L}^{-1}$ a $10^{-4}$ mol L-1 com limite de detecção e quantificação de $4,41 \times 10^{-6} \mathrm{~mol} \mathrm{~L}^{-1}$ e $6,21 \times 10^{-6} \mathrm{~mol} \mathrm{~L}^{-1}$, respectivamente. Além disso, a sensibilidade do eletrodo não modificado com nanotubos foi $0,01 \mu \mathrm{A}$ per $\mu \mathrm{mol} \mathrm{L}^{-1}$, consideravelmente menor que os valores de 5,34 e 6,97 $\mu \mathrm{A}$ per $\mu \mathrm{mol} \mathrm{L^{-1 }}$ obtidos usando nanotubos oxidados de carbono de parede múltipla (pequenos e longos), respectivamente.
\end{abstract}

1-Methyl-4-nitro-2-brominemethylimidazole (4-NimMeBr), was electrochemically reduced on mercury, glassy carbon and multiwalled carbon nanotubes (MWCNT) modified electrodes. 4-NimMeBr was adsorbed on the MWCNT modified electrode thus permitting the implementation of an adsorptive stripping voltammetric (ASV) method. We have used 4-NimMeBr as a prototype electroactive nitro compound to study the effect of both the size of the nanotubes and its functionalization by oxidation. The oxidized MWCNT forms better dispersions than the non-oxidized, producing electrode surface with higher density of MWCNT as was determined by electrochemical mapping using scanning electrochemical microscopy (SECM). Under the optimized conditions, the peak current was proportional to the concentration of 4-NimMeBr in the range of $10^{-6} \mathrm{~mol} \mathrm{~L}^{-1}$ to $10^{-4} \mathrm{~mol} \mathrm{~L}^{-1}$ with detection and quantification limits of $4.41 \times 10^{-6} \mathrm{~mol} \mathrm{~L}^{-1}$ and $6.21 \times 10^{-6} \mathrm{~mol} \mathrm{~L}^{-1}$, respectively. The sensibility of bare electrode was $0.01 \mu \mathrm{A}$ per $\mu \mathrm{mol} \mathrm{L}{ }^{-1}$, which was lower than the value of 5.34 and $6.97 \mu \mathrm{A}$ per $\mu \mathrm{mol} \mathrm{L}^{-1}$ obtained using short and large oxidized MWCNT, respectively.

Keywords: 4-nitroimidazole, carbon nanotubes, adsorptive stripping voltammetry, scanning electrochemical microscopy

\section{Introduction}

The study of the electrochemistry of nitro compounds began early in 1900, when Haber ${ }^{1}$ revealed the stepwise reduction of nitrobenzene, but there is still a great interest in this type of compounds. One reason for such interest is that numerous nitro compounds are manufactured for use

*e-mail: asquella@ciq.uchile.cl as pharmaceuticals and consequently they are introduced into living organisms and metabolized often via redox type processes. Compounds with the most extensive clinical application in this capacity are nitroimidazoles that have been employed in the treatment of anaerobic infections and in cancer treatment as hypoxic cell cytotoxins and radiation sensitizers. ${ }^{2,3}$ Due to his pharmacological activities, the synthesis of new nitroimidazole compounds remains as a very active area of research. ${ }^{4-6}$ It is a well known matter 
that the biological activity of nitroimidazole compounds is related to the redox chemistry of the nitro group. ${ }^{7}$ This aspect has motivated a great number of electrochemical studies and consequently, the redox chemistry of different nitro compounds of biological significance is focused to understand how the reduction of the nitro group can play an active role in several aspects as: electroanalytical determinations, free radical generation, stability and reactivity. ${ }^{8}$

From the electroanalytical point of view the most useful signal for quantitative purposes is the four electron four-proton signal due to the reduction of the nitro group to produce the hydroxylamine derivative. The advantages of this signal are both the high quantity of current produced per mol of electroactive compound and the relative low energy requirements for the nitro reduction. Therefore we can obtain high current/concentration ratios and low reduction potentials. These advantages have permitted the development of a great quantity of electrochemical methods applied to nitroimidazole derivatives using different techniques such as: cyclic voltammetry, ${ }^{9} 10$ square wave adsorptive stripping voltammetry, ${ }^{11}$ cathodic adsorptive voltammetry. ${ }^{12}$

On the other hand, the use of multi walled carbon nanotubes (MWCNT) as electrode material has been increasing due to its unique properties, including their remarkable electrical, chemical, mechanical and structural properties. ${ }^{13}$ Furthermore, recently some studies have shown that different types of MWCNT modified electrodes exhibit attractive electrochemical properties producing electrocatalytic effects. ${ }^{14-16}$

There are only few papers devoted to applications of carbon nanotubes on nitro compounds. Simple and sensitive electrochemical methods for the detection of ultratrace levels of 2,4,6-trinitrotoluene on glassy carbon electrodes modified with MWCNT has been published. ${ }^{17}$ More recently, the electrochemical reduction of nitrophenol isomers at a glassy carbon electrode modified with MWCNT, ${ }^{18}$ the electrochemical reduction of nitrobenzene at MWCNT electrode,,$^{19}$ and the voltammetric reduction of a 4-nitroimidazole derivative on a multiwalled MWCNT modified electrode ${ }^{20}$ have been published. However, none of these studies have reported the effect of size and functionalization of nanotubes in the analytical response of the nitro derivative.

In the present study we have centered our attention on the electrochemical behavior of $4-\mathrm{NimMeBr}$ in order to obtain a voltammetric method to determine it on a MWCNT-modified electrode. Especially we studied the influence of both size of nanotubes and its functionalization by acid oxidation on the analytical determination of this nitro derivative.

\section{Experimental}

\section{Reagents and solutions}

4-NimMeBr (Figure 1) was synthesized and characterized in our laboratory.

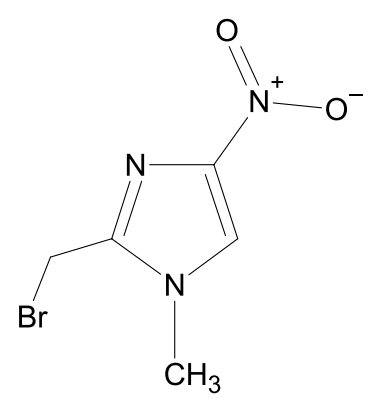

Figure 1. Molecular structure of 1-methyl-4-nitro-2-brominemethylimidazole (4-NimMeBr).

MWCNT 1-5 $\mu \mathrm{m}$ large (short type) or 5-20 $\mu \mathrm{m}$ large (long type) and $(30 \pm 15) \mathrm{nm}$ diameter were obtained from Nano-Lab (USA). MWCNT were oxidized by chemical treatment with a mixture $3: 1$ of $3 \mathrm{~mol} \mathrm{~L}^{-1} \mathrm{H}_{2} \mathrm{SO}_{4}: 3 \mathrm{~mol} \mathrm{~L}^{-1}$ $\mathrm{HNO}_{3}$ by refluxing for $3 \mathrm{~h}$. After that, the suspension was filtered and washed with water until neutral $\mathrm{pH}$. All the other reagents employed were of analytical grade. Nitrogen gas was obtained from AGA Chile S.A. with maximum impurities of $\mathrm{H}_{2} \mathrm{O}<3 \mathrm{ppm} ; \mathrm{O}_{2}<2$ ppm; $\mathrm{C}_{\mathrm{n}} \mathrm{H}_{\mathrm{m}}<0.5 \mathrm{ppm}$.

All the voltammetric experiments were obtained after bubbling with $\mathrm{N}_{2}$ for $10 \mathrm{~min}$ in the cell before each run. Temperature was kept constant at $25 \pm 0.1{ }^{\circ} \mathrm{C}$ in all experiments.

Britton-Robinson buffer $0.1 \mathrm{~mol} \mathrm{~L}^{-1}$ (boric acid, phosphoric acid and acetic acid, $0.1 \mathrm{~mol} \mathrm{~L}^{-1}$ ) was used for aqueous media. All aqueous solutions were prepared with deionized water purified with Milli-Q Ultra-Pure Water System.

Stock solutions of $4-\mathrm{NimMeBr}$ were prepared at a constant concentration of $10^{-2} \mathrm{~mol} \mathrm{~L}^{-1}$ in Britton-Robinson buffer. The polarographic and cyclic voltammetric working solutions were prepared by diluting the stock solution.

\section{Apparatus}

Electrochemical measurements were recorded on electrochemical analizer BAS CV-50W (bioanalytical system) attached to a PC computer with appropriate software (BAS 100W 2.3 for Windows) for total control of the experiments and data acquisition and treatment.

A conventional three-electrode cell was used. Glassy carbon electrode (GCE) of $3 \mathrm{~mm}$ diameter (model 
CHI104, CH Instruments) was used as working electrode for differential pulse voltammetry (DPV), linear sweep voltammetry (LSV) and cyclic voltammetry (CV).

A controlled-growth mercury electrode (CGME) polarographic stand was used with a dropping mercury electrode (DME) as the working electrode for differential pulse polarography (DPP). A platinum wire (BASiMW-1032) as the counter electrode and an $\mathrm{Ag} / \mathrm{AgCl} / \mathrm{NaCl}\left(3 \mathrm{~mol} \mathrm{~L}^{-1}\right)(\mathrm{BASi} \mathrm{MF}-2052)$, as the reference electrode, were used.

A magnetic stirrer was utilized for accumulation of 4-NimMeBr on electrode surface.

Scanning electrochemical microscopy (SECM) measurements were performed with a CHI 900 setup (CH Instrument Inc., USA). For SECM measurements a $10 \mathrm{~mm}$ diameter homemade carbon fibber electrode served as SECM tip while GCE modified and unmodified with MWCNT were used as SECM substrate. A platinum wire (BASiMW-1032) as the counter electrode and an $\mathrm{Ag} / \mathrm{AgCl} / \mathrm{NaCl}\left(3 \mathrm{~mol} \mathrm{~L}^{-1}\right)$ (BASi MF-2052), as the reference electrode, were used. Ferrocene methanol $(\mathrm{FcOH})$ $1 \mathrm{mmol} \mathrm{L}^{-1}$ in phosphate buffer solution $\mathrm{pH} 7.40$ was used as a redox mediator.

\section{Procedures}

\section{Synthesis of 4-NimMeBr}

It was dissolved $1 \mathrm{~g}(4.54 \mathrm{mmol})$ of $4-\mathrm{NimMeOH}^{21}$ in the minimal volume of pyridine that is possible obtaining a slightly colored solution (yellow very clear). Then $700 \mu \mathrm{L}$ of $\mathrm{SOBr}_{2}$ were added, the resultant mixture changed to an orange intense color, then heat to reflux with agitation by $3 \mathrm{~h}$. A yellow precipitate was observed, filtered at vacuum and washed repeatedly with cold acetone to eliminate the excess of pyridine. The product, $40 \%$ render, was crystallized in ethanol. The solid re-crystallizes in methanol obtaining white crystals.

The physical and chemical characterization of this compound gave the following results: ${ }^{1} \mathrm{H}$ NMR $(300 \mathrm{MHz}$, DMSO-d $\left.{ }_{6}\right): \delta 4.9\left(\mathrm{~s}, 3 \mathrm{H}, \mathrm{NCH}_{3}\right) 7.2\left(\mathrm{~s}, 2 \mathrm{H}, \mathrm{CH}_{2}\right) 9.6(\mathrm{~s}, 1 \mathrm{H}$, $-\mathrm{C}=\mathrm{CH}-\mathrm{N}-\mathrm{CH}_{3}$ ). Elemental analysis, calc.: $\mathrm{C}: 27.27 \%$; H: $2.72 \%$ and N: $19.09 \%$; found: C: $26.71 \%$; H: $2.88 \%$ and $\mathrm{N}: 18.23 \%$; mp $219-220^{\circ} \mathrm{C}$.

\section{Preparation of MWCNT suspension and modified GCE}

Before each modification, the GCE was cleaned by polishing with $0.3 \mu \mathrm{m}$ and $0.05 \mu \mathrm{m}$ alumina, and then was washed with abundant water. The oxidized MWCNT were dispersed at different concentrations $\left(\mathrm{mg} \mathrm{mL}^{-1}\right)$ with water by sonication for $5 \mathrm{~min}$. The sonication procedure was repeated three times. The immobilization of MWCNT was performed by casting the GCE with $5 \mu \mathrm{L}$ of the MWCNT dispersion just after sonication. The optimum conditions were obtained drying the dispersion dropped onto the GCE for $15 \mathrm{~min}$ at $50^{\circ} \mathrm{C}$ in a stove.

\section{4-NimMeBr adsorption}

The modified GCE electrode was immersed in a stirred $(250 \mathrm{rpm})$ supporting buffer solution containing 4-NimMeBr; the accumulation time was variable and no potential was applied during this step.

\section{Voltammetric transduction}

It was performed by LSV. The cathodic peak current at around $-400 \mathrm{mV}$, corresponding to the nitro reduction, was used as analytical signal.

\section{Images by SECM}

Approach curves and images were obtained following the procedure previously described..$^{22}$ Specifically, the tip potential was held at $600 \mathrm{mV}$ to produce the oxidation of $\mathrm{FcOH}$ (FcOHox), while the substrate potential was held at $-100 \mathrm{mV}$ to permit the feedback between the electrodes, since $\mathrm{FcOHox}$ generated at the tip is reduced at this potential regenerating the parent $\mathrm{FcOH}$.

Part of the film (no more than $1 / 3$ of the surface) was removed from the glassy carbon modified electrode. Then, an approach curve was conducted on the exposed glassy carbon surface at a tip scan rate of $0.5 \mu \mathrm{m} \mathrm{s}^{-1}$. When the tip is far from the substrate and the potencial is applied, FcOHox is generated and the steady-state current $i_{T, \infty}$ is obtained. When the tip is brought close to the substrate a current $i_{\mathrm{T}}$ is observed due to the formation of $\mathrm{FcOH}$. The tip was stopped when $i_{\mathrm{T}}$ reaches 1.25 times the value of $i_{\mathrm{T}, \infty}$. According to the theoretical curve that describes the dependence of the $i_{\mathrm{T}}$ with the distance between the tip and the substrate (d), 1.25 times of $i_{\mathrm{T}, \infty}$ corresponds to a $\mathrm{d} c a .10 \mu \mathrm{m}$, when a $5 \mathrm{~mm}$ tip radius is used. ${ }^{23}$ After the approach curve, the tip was moved in the $\mathrm{x}$ direction to make sure that the tip is over the film and a series of constant height $100 \mu \mathrm{m} \times 100 \mu \mathrm{m}$ area SECM images were recorded at a tip scan rate of $1 \mathrm{~mm} \mathrm{~s}^{-1}$. The results are presented in the dimensionless form of $i_{\mathrm{T}}$, by normalizing the experimental feedback current $\left(i_{\mathrm{T}}\right)$ by the steady-state current obtained when the tip was far from the substrate $\left(i_{\mathrm{T}, \infty}\right)$, i.e., $\left(I_{\mathrm{T}}=i_{\mathrm{T}} / i_{\mathrm{T}, \infty}\right)$.

\section{Results and Discussion}

A new synthesized compound, 4-NimMeBr, was electrochemically reduced at mercury electrode in aqueous 
media $100 \%$ Britton-Robinson $0.1 \mathrm{~mol} \mathrm{~L}^{-1}$. Only one cathodic peak in all the $\mathrm{pH}$ range was detected (Figure 2A).
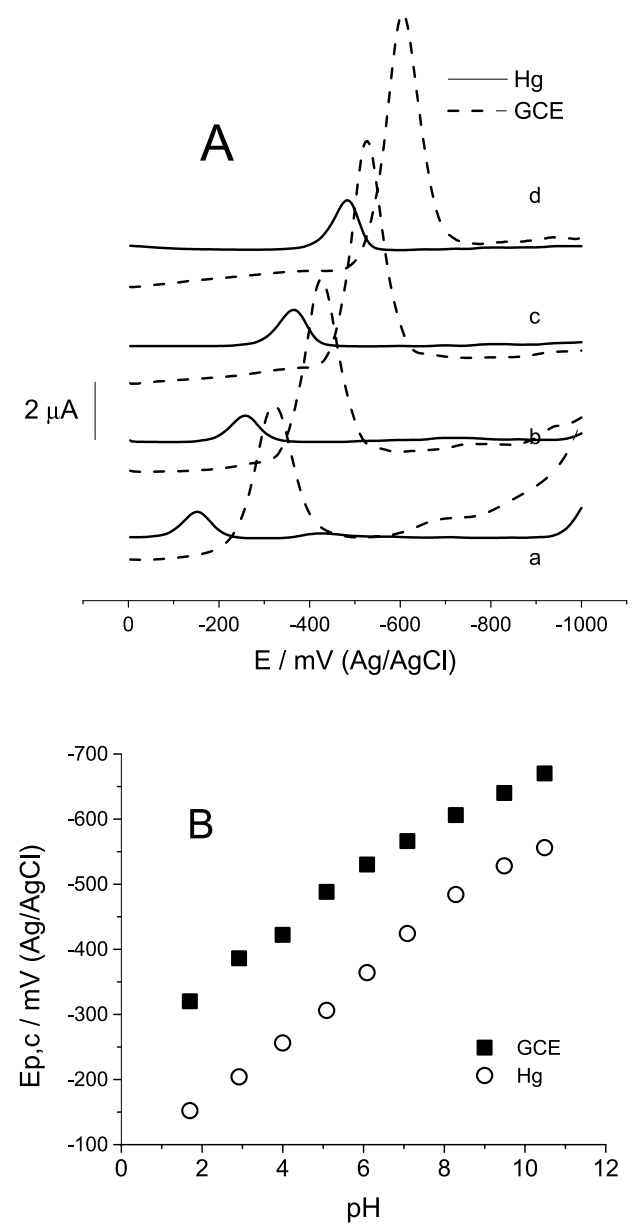

Figure 2. (A) Differential pulse polarograms (Hg electrode) and voltammograms (GCE) of $0.1 \mathrm{mmol} \mathrm{L}^{-1} 4-\mathrm{NimMeBr}$ in $0.1 \mathrm{~mol} \mathrm{~L}^{-1}$ Britton-Robinson buffer at different pH values, 1.7 (a), 4.0 (b), 6.1 (c), 8.3 (d). General parameters DPP: initial E: $0 \mathrm{mV}$, final E: $-1000 \mathrm{mV}$, sensitivity: $10 \mu \mathrm{A} \mathrm{V}^{-1}$. Specific parameters DPP: scan rate: $4 \mathrm{mVs}^{-1}$, pulse amplitude: $50 \mathrm{mV}$, sample width: $17 \mathrm{~ms}$, pulse width: $50 \mathrm{~ms}$, drop time: $1000 \mathrm{~ms}$, quiet time: $0 \mathrm{~s}$. General parameters DPV: initial E: $0 \mathrm{mV}$, final $\mathrm{E}:-1000 \mathrm{mV}$, sensitivity: $10 \mu \mathrm{A} \mathrm{V}^{-1}$. Specific parameters DPV: scan rate: $20 \mathrm{mVs}^{-1}$, pulse amplitude: $50 \mathrm{mV}$, sample width: $17 \mathrm{~ms}$, pulse width: $50 \mathrm{~ms}$, pulse period: $200 \mathrm{~ms}$, quiet time: $2 \mathrm{~s}$. (B) The corresponding peak potential (Ep) dependence with $\mathrm{pH}$.

The peak has a cathodic peak potential, $\mathrm{E}_{\mathrm{p}, \mathrm{c}}$ of $-450 \mathrm{mV}$ at $\mathrm{pH} 7$ and the peak was strongly $\mathrm{pH}$-dependent $(\mathrm{Hg}$ electrode). In order to study the $\mathrm{pH}$ influence on the nitro reduction we have evaluated the behavior of the peak potential, (Ep) obtained by DPP or DPV at different $\mathrm{pH}$ values between 2 and 11. In the Figure 2B, the Ep vs. pH plot shows that the peak potential is $\mathrm{pH}$-dependent shifting to more negative potentials when $\mathrm{pH}$ increased. From these results we can observe that the obtained Ep values are very similar with the previously reported ${ }^{21}$ for other 4-nitroimidazole analogue permitting to conclude that the change in the 2-position substitution did not change the reduction of the 4-nitroimidazole moiety. Furthermore from the comparison of the peak potentials between $\mathrm{Hg}$ and GCE we can assume that the reduction of nitroimidazole derivative is favoured on $\mathrm{Hg}$.

The cyclic voltammogram (data not shown) of 4-NimMeBr in aqueous media also shows a single peak with not signal in the anodic sweep, which indicates that this peak corresponds to an irreversible process. According to the well-known mechanism of 4-nitroimidazole derivatives ${ }^{20,21}$ we can assume that the observed irreversible peak in all the $\mathrm{pH}$ range is due to the four-electron, fourproton reduction of the nitroimidazole group to yield the hydroxylamine derivative according to the following overall reaction:

$\mathrm{RNO}_{2}+4 \mathrm{e}^{-}+4 \mathrm{H}^{+} \rightarrow \mathrm{RNHOH}+\mathrm{H}_{2} \mathrm{O}$

The voltammetric responses of $9.8 \times 10^{-5} \mathrm{~mol} \mathrm{~L}^{-1}$ of 4-NimMeBr on a GCE occurs in a similar way to that reported on $\mathrm{Hg}$, i.e., one irreversible peak or wave in aqueous media (Britton-Robinson buffer $0.1 \mathrm{~mol} \mathrm{~L}^{-1}, \mathrm{pH} 2$ ) is observed (Figure 3). This Figure shows the comparison of voltammograms of $4-\mathrm{NimMeBr}$ obtained over the same bare polished GCE but with and without 4 min of accumulation time.

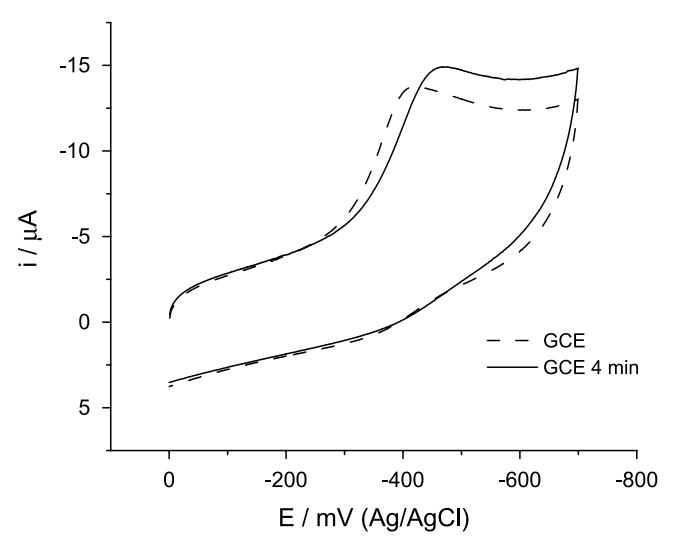

Figure 3. Cyclic voltammograms of 4-NimMeBr at GCE, without accumulation (dashed line), and after $4 \mathrm{~min}$ accumulation time (solid line); in $0.1 \mathrm{~mol} \mathrm{~L}^{-1}$ Britton-Robinson buffer, $\mathrm{pH} \mathrm{2}$; scan rate: $100 \mathrm{mV} \mathrm{s}^{-1}$.

After accumulation time is not observed a change in the peak current, however, a little displacement toward more negative potentials in approximately $50 \mathrm{mV}$ is observed. Obviously this result implies that $4-\mathrm{NimMeBr}$ is not adsorbed on the bare GCE.

In order to study the optimal response for the reduction peak of 4-NimMeBr we have tested the modification of the glassy carbon electrode with MWCNT.

Figure 4 shows the voltammograms of $4-\mathrm{NimMeBr}$ obtained at two different electrodes, i.e. bare GCE and 
MWCNT/GCE prepared using a dispersion of $1 \mathrm{mg} \mathrm{mL}^{-1}$ MWCNT in water. Using a $1 \times 10^{-4} \mathrm{~mol} \mathrm{~L}^{-1}$ solution of 4-NimMeBr in $0.1 \mathrm{~mol} \mathrm{~L}^{-1}$ Britton-Robinson buffer at $\mathrm{pH} 2$ it was found an important difference in the sensitivity of the current signals, being the current obtained on the MWCNT/ GCE higher than the obtained from the bare electrode.

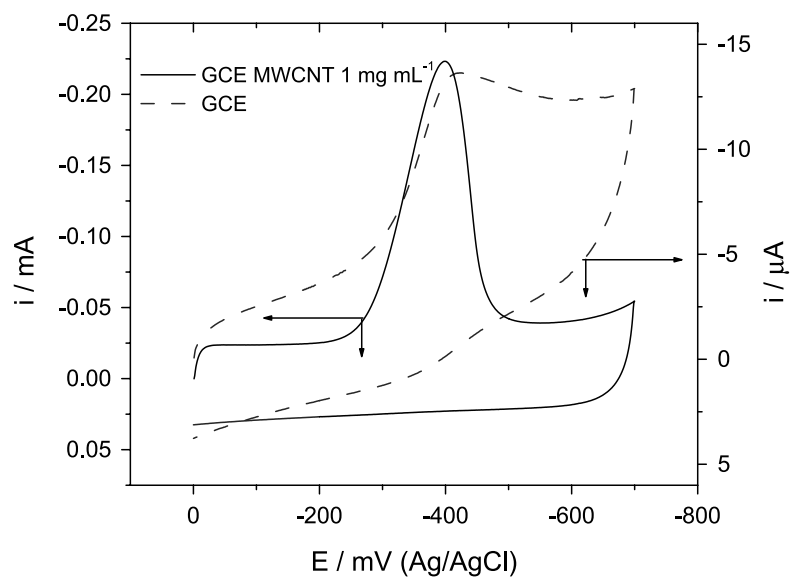

Figure 4. Cyclic voltammograms of 4-NimMeBr at GCE (dashed line) and MWCNT/GCE using $1 \mathrm{mg} \mathrm{mL}^{-1}$ MWCNT dispersion (solid line); $0.1 \mathrm{~mol} \mathrm{~L}^{-1}$ Britton-Robinson buffer, $\mathrm{pH}$ 2. Scan rate: $100 \mathrm{mV} \mathrm{s}^{-1}$.

On the other hand the film homogeneity and thickness can be regulated with the concentration of the dispersion. In Figure 5 the MWCNT concentration effect of the MWCNT dispersion on the reduction peak current of $4-\mathrm{NimMeBr}$ is showed.

The results suggested that the film formation is a progressive process that reaches a saturation point near to $4.0 \mathrm{mg} \mathrm{mL}^{-1}$. On the other hand, more concentrated MWCNT dispersions produce unstable films which increase the relative standard deviation (RSD) of the measurement. Consequently a recommended concentration

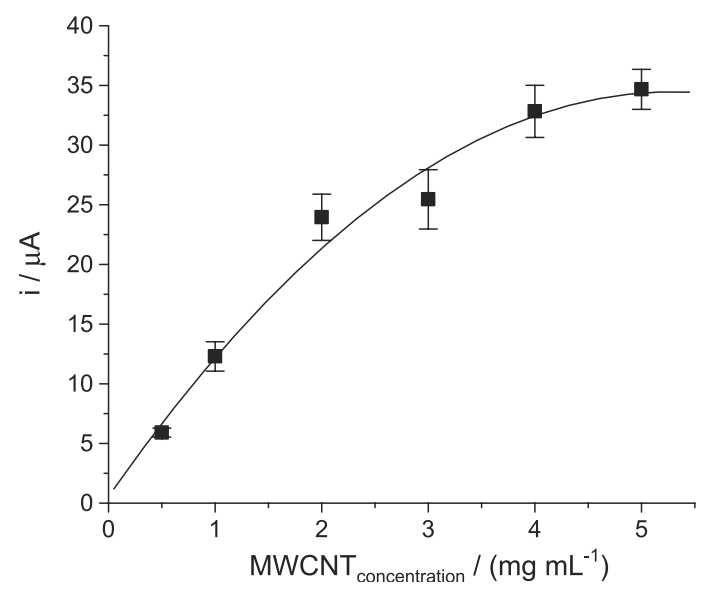

Figure 5. Peak current dependence with the MWCNT concentration. 4-NimMeBr concentration: $9.8 \times 10^{-5} \mathrm{~mol} \mathrm{~L}^{-1}$. MWCNT dispersed in water. Each measurement was obtained as the mean of 5 independents runs and bars show the RSD. Other experimental conditions are as in Figure 4. for the dispersion is $4.0 \mathrm{mg} \mathrm{mL}^{-1}$ of MWCNT in water for obtaining a better current signal.

The considerable enhancement in the reduction peak current is in part attributed to the strong adsorptive ability of the MWCNT film on GCE. This fact can be corroborated studying the dependence of peak current with the accumulation time of the 4-NimMeBr nitro derivative.

Figure 6 shows LSV of 4-NimMeBr showing the effect of the accumulation time at open-circuit on the reduction peak current of $4-\mathrm{NimMeBr}\left(1.02 \times 10^{-5} \mathrm{~mol} \mathrm{~L}^{-1}\right)$ using a MWCNT concentration of $4 \mathrm{mg} \mathrm{mL}^{-1}$. The reduction peak current increases greatly within the first 4 min and then reaches a plateau indicating saturation at the MWCNT electrode. On the other hand the potential peak value did not change at different accumulation times.

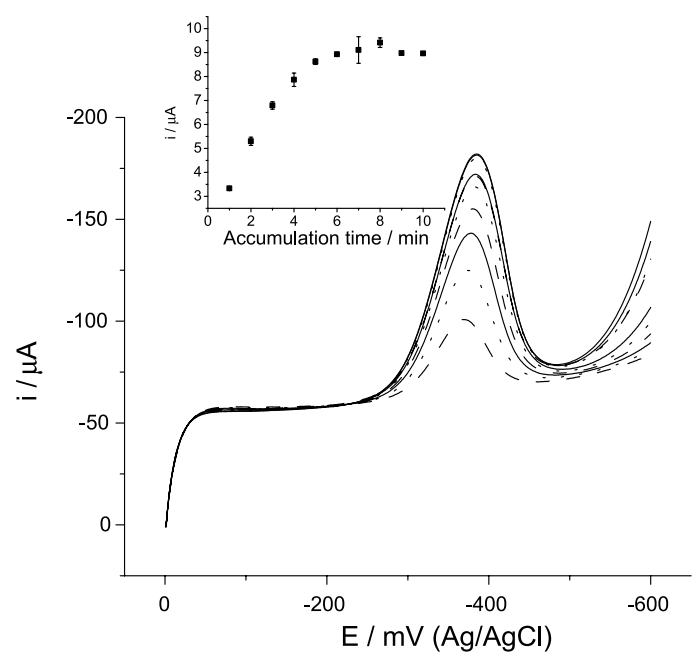

Figure 6. Linear sweep voltammograms of 4-NimMeBr at MWCNT/ GCE electrode at different accumulation times. Scan rate $=100 \mathrm{mV} \mathrm{s}^{-1}$ Inset: Dependence of the peak current with the accumulation time. [4-NimMeBr]: $1.02 \times 10^{-5} \mathrm{~mol} \mathrm{~L}^{-1}$. MWCNT: $4 \mathrm{mg} \mathrm{mL}^{-1}$. $0.1 \mathrm{~mol} \mathrm{~L}^{-1}$ Britton-Robinson buffer, $\mathrm{pH}$ 2. Each measurement was obtained as the mean of 5 independents runs and bars show the RSD.

Also we have tested if both the type of nanotubes and its functionalization by oxidation affect the response with respect to accumulation time. In this scope we have compared short non-oxidized nanotubes (CNTsnox) with both short (CNTsox) and long (CNTlox) oxidized nanotubes.

The non-oxidized nanotubes obtained the saturated point around 2 min accumulation while the oxidized ones (short and long) about 6 min, showing a significant difference in current intensity (Figure 7). From these experiments is clear that the size of the MWCNT did not affect significantly the current response, however, the oxidized MWCNT produce a modified electrode much more sensitive than the non-oxidized MWCNT. 


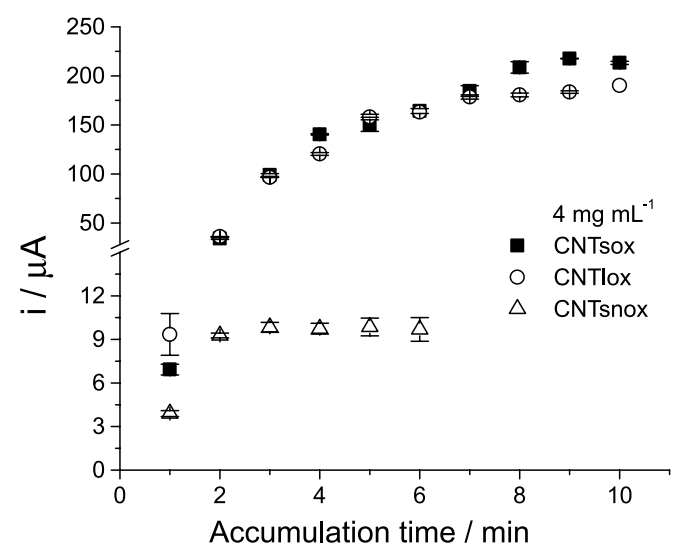

Figure 7. Dependence of the peak current with the accumulation time on GCE modified with different MWCNT: MWCNT short and oxidized $=$ CNTsox; MWCNT large and oxidized $=$ CNTlox; MWCNT short and non-oxidized $=$ CNTsnox. [4-NimMeBr]: $3 \times 10^{-6} \mathrm{~mol} \mathrm{~L}^{-1}$. MWCNT: $4 \mathrm{mg} \mathrm{mL}^{-1}, 0.1 \mathrm{~mol} \mathrm{~L}^{-1}$ Britton-Robinson buffer, $\mathrm{pH}$ 2. (Obtained with $\mathrm{LSV}$, scan rate $100 \mathrm{mV} \mathrm{s}^{-1}$ ).

In order to study with major deep this result we have used SECM to electrochemically map the electrode surface. In Figure 8 we show the SECM images of the electrode surfaces of three different electrodes, i.e., bare GCE, GCE modified with both oxidized and non-oxidized MWCNT.

In the case of oxidized MWCNT it is clear a major cover of the surface by the MWCNT thus explaining the better accumulation ability of the nitroimidazole on this type of MWCNT. On the other hand the higher cover is due to that the functionalization of the MWCNT increases the dispersion of the MWCNT in water. Summarizing, the oxidized MWCNT forms better dispersions than the non-oxidized, producing electrode surface with higher density of MWCNT. Furthermore, the functionalization can create defects on the MWCNT surface exposing more edge plane sites and/or increasing the exposed area of the same. These new highly reactive areas (edge plane when compared with basal plane) could be also responsible for the better accumulation of the nitroimidazole and not only a better dispersion of the CNTs.

Considering the capacity of 4-NimMeBr to be adsorbed in the modified electrode we developed an ASV method to quantify this compound. The first step of the ASV method involves the accumulation of $4-\mathrm{NimMeBr}$ in the MWCNT modified electrodes and the second step involves the stripping of the adsorbed $4-\mathrm{NimMeBr}$ using a linear sweep potential.

Consequently, we have studied the $4-\mathrm{NimMeBr}$ concentration dependence with the peak current. We constructed calibration curves comparing the bare GCE (using LSV technique) with modified electrodes using both large and short oxidized MWCNT (using ASV technique).
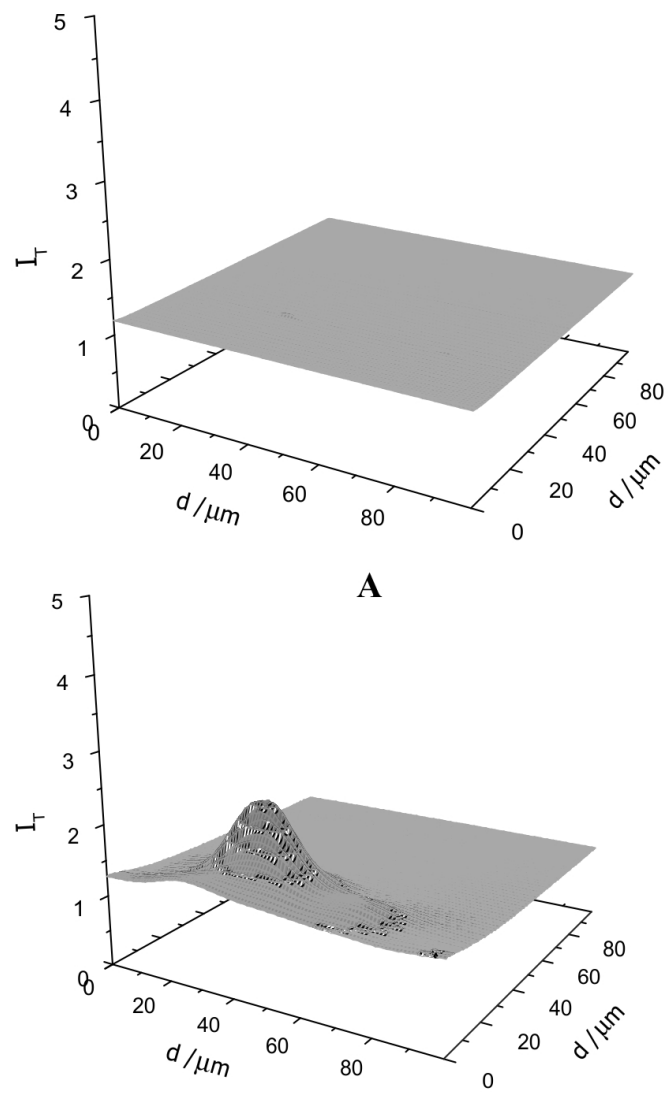

B

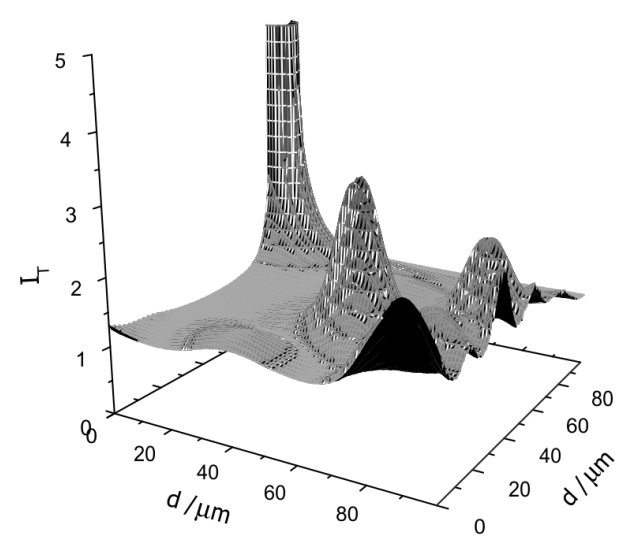

$\mathrm{C}$

Figure 8. SECM surface-plot images of GCE (A), MWCNT modified electrode (B) and MWCNTsox modified electrode (C). Concentration of dispersion: $1 \mathrm{mg} \mathrm{mL}^{-1}, 1 \mathrm{mmol} \mathrm{L}^{-1} \mathrm{FcOH}$ in $0.2 \mathrm{~mol} \mathrm{~L}^{-1}$ phosphate buffer $(\mathrm{pH}$ 7.4) was used as a redox mediator.

From the slope of these curves (Figure 9) it is possible to appreciate considerable differences in the analytical sensibility between bare and modified electrodes. In the case of the bare electrode a sensibility of $0.01 \mu \mathrm{A}$ per $\mu \mathrm{mol} \mathrm{L} \mathrm{L}^{-1}$ was obtained, which was considerable lower than the value of 5.34 and $6.97 \mu \mathrm{A}$ per $\mu \mathrm{mol} \mathrm{L}^{-1}$ obtained using short and large oxidized MWCNT, respectively. 


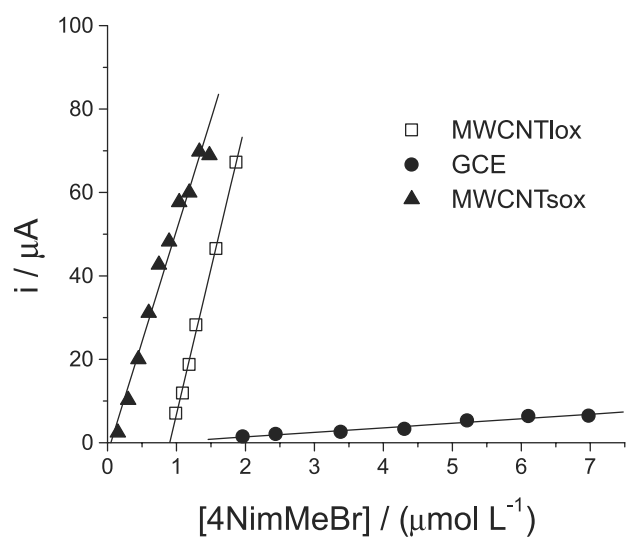

Figure 9. Calibration curves of $4-\mathrm{NimMeBr}$ obtained at bare GCE $\left(\mathrm{i}_{\mathrm{p}}:-0.77+0.01[4-\mathrm{NimMeBr}]\right)$ at modified with both large (CNTlox) ( $\left.\mathrm{i}_{\mathrm{p}}:-62.86+6.97[4-\mathrm{NimMeBr}]\right)$ and short (CNTsox) (ip: $-2.52+5.34[4-\mathrm{NimMeBr}]$ ) oxidized MWCNT. MWCNT: $4 \mathrm{mg} \mathrm{mL}^{-1}$ $0.1 \mathrm{~mol} \mathrm{~L}^{-1}$ Britton-Robinson buffer, $\mathrm{pH}$ 2. Scan rate: $100 \mathrm{mV} \mathrm{s}^{-1}$. Curves were obtained using LSV (bare GCE) or ASV (Modified GCE) techniques.

The repeatability was evaluated in the same 4-NimMeBr solution by ten consecutive measurements of the peak current in the same electrode. The results show a $2.9 \%$ for the variation coefficient, showing good repeatability and stability of the film. On the other hand if the experiments were carried out using accumulation time of $6 \mathrm{~min}$, concentration of the CNTlox dispersion of $4 \mathrm{mg} \mathrm{mL}^{-1}$, $\mathrm{pH} 2.0$ we obtained detection and quantification limits of $4.41 \times 10^{-6} \mathrm{~mol} \mathrm{~L}^{-1}$ and $6.21 \times 10^{-6} \mathrm{~mol} \mathrm{~L}^{-1}$, respectively. The CNTsox showed detection and quantification limits of $8.07 \times 10^{-6} \mathrm{~mol} \mathrm{~L}^{-1}$ and $11.36 \times 10^{-6} \mathrm{~mol} \mathrm{~L}^{-1}$. According to the above results the best conditions for the ASV developed method were obtained with oxidized nanotubes obtaining an increased sensibility of about 1000 times compared with the bare electrode.

\section{Conclusions}

The electrochemical reduction of $4-\mathrm{NimMeBr}$ in aqueous medium, on carbon electrodes (bare GCE or modified GCE) occurs via one irreversible 4-electron 4-proton wave in a similar way that on mercury electrodes. In spite of no changes in the mechanism was observed considerable differences in peak current when changing from bare to modified electrodes are observed.

The 4-NimMeBr shows highly effective accumulation on modified electrodes with oxidized MWCNT resulting in a significant improvement in sensitivity allowing analytical applications as ASV.

The use of SECM permitted to map the electrode surface thus differentiating a different coverage grade depending if oxidized or non-oxidized MWCNT were used. The oxidized MWCNT formed better dispersions than the non-oxidized, producing electrode surface with higher density of MWCNT. On the other hand the size of the MWCNT did not affect significantly the analytical response of nitroimidazole derivative.

\section{Acknowledgments}

The authors are grateful to FONDECYT (Grant No. 1090120) for support of this work.

\section{References}

1. Lund, H. In Organic Electrochemistry; Lund, H.; Hammerich, O., eds.; $4^{\text {th }}$ ed., Marcel Dekker Inc., NY, 2001, ch. 9, p. 379.

2. Riché, F.; du Molinet, A.; Sèpe, S.; Riou, L.; Fagret, D.; Vidal, M.; Bioorg. Med. Chem. Lett. 2001, 11, 71.

3. Edwards, D. I.; J. Antimicrob. Chemother. 1993, 31, 9.

4. Kim, P.; Zhang, L.; Manjunatha, U.; Singh, R.; Patel, S.; Jiricek, J.; Keller, T.; Boshoff, H.; Barry, C.; Dowd, C.; J. Med. Chem. 2009, 52, 1317.

5. Valdez, C.; Tripp, J.; Miyamoto, Y.; Kalisiak, J.; Hruz, P.; Andersen, Y.; Brown, S.; Kangas, K.; Arzu, L.; Davids, B.; Gillin, F.; Upcroft, J.; Upcroft, P.; Fokin, V.; Smith, D.; Sharpless, K.; Eckmann, L.; J. Med. Chem. 2009, 52, 4038.

6. Kim, P.; Kang, S.; Boshoff, H.; Jiricek, J.; Collins, M.; Singh, R.; Manjunatha, U.; Niyomrattanakit, P.; Zhang, L.; Goodwin, M.; Dick, T.; Keller, T.; Dowd, C.; Barry, C.; J. Med. Chem. 2009, 52, 1329.

7. Edwards, D. I.; Biochem. Pharmacol. 1986, 35, 53.

8. Squella, J. A.; Bollo, S.; Núñez-Vergara, L. J.; Curr. Org. Chem. 2005, $9,565$.

9. Squella, J.A.; Campero, A.; Maraver, J.; Carbajo, J.; Electrochim. Acta 2006, 52, 511.

10. Bollo, S.; Núñez-Vergara, L. J.; Bontá, M.; Chauviere, G.; Périé, J.; Squella, J. A.; J. Electroanal. Chem. 2001, 511, 46.

11. Bartlett, P. N.; Ghoneim, E.; El-Hefnawy, G.; El-Hallag, I.; Talanta 2005, 66, 869.

12. El-Sayed, G. O.; Yasin, S. A.; El Badawy, A. A.; Arabian Journal of Chemistry 2010, 3, 167.

13. Wang, J.; Electroanalysis 2005, 17, 7.

14. Banks, C. E.; Davies, T. J.; Wildgoose, G. G.; Compton, R. G.; Chem. Commun. 2005, 7, 829.

15. Cui, H. F.; Ye, J.-S.; Zhang,W.-D.; Wang, J.; Sheu, F.-S.; J. Electroanal. Chem. 2005, 577, 295.

16. Yang, S.; Zeng, X.; Liu, X.; Wei, W.; Luo, S.; Liu, Y.; Liu. Y.; J. Electroanal.Chem. 2010, 639, 181.

17. Wang, J.; Samo, P.; Hocevar, B.; Ogorevc, B.; Electrochem. Commun. 2004, 6, 176.

18. Luo, L.-q.; Zou, X.-1.; Ding, Y.-p.; Wu, Q.-s.; Sens. Actuators, B 2008, 135, 61.

19. Li, Y.-P.; Cao, H.-B.; Liu, C.-M.; Yi, Z.; J. Hazard. Mater. 2007, $148,158$. 
20. Jara-Ulloa, P.; Bollo, S.; Núñez-Vergara, L. J.; Squella, J. A.; Electroanalysis 2008, 20, 1470.

21. Yañez, C.; Pezoa, J.; Rodríguez, M.; Núñez-Vergara, L. J.; Squella, J. A.; J. Electrochem. Soc. 2005, 152, J46.

22. Bollo, S.; Ferreyra, N. F.; Rivas, G. A.; Electroanalysis 2007, 19, 833.
23. Bard, A. J.; Mirkin, M. V.; Scanning Electrochemical Microscopy, Marcel Dekker Inc.: New York, 2001.

Submitted: November 15, 2010

Published online: March 3, 2011 